\title{
Probiotics prevent enterohaemorrhagic Escherichia coli O157 : H7-mediated inhibition of interferon- $\gamma$ - induced tyrosine phosphorylation of STAT-1
}

\begin{abstract}
Correspondence
Philip M. Sherman

philip.sherman@sickkids.ca
\end{abstract}

Received 7 July 2008

Revised 3 November 2008

Accepted 5 November 2008

\author{
Narveen Jandu, Zoë Jingjing Zeng, Kathene C. Johnson-Henry \\ and Philip M. Sherman
}

Research Institute, Hospital for Sick Children, University of Toronto, Toronto, ON, Canada

\begin{abstract}
Enterohaemorrhagic Escherichia coli (EHEC) O157:H7 inhibits interferon (IFN)- $\gamma$-stimulated tyrosine phosphorylation of signal transducer and activator of transcription (STAT)-1 in epithelial cells. We determined the effects of probiotics on EHEC-mediated disruption of IFN- $\gamma$-stimulated STAT-1 activation in epithelial cell lines. Confluent Intestine 407, HEp-2 and Caco-2 epithelial cells were pre-treated $(3 \mathrm{~h})$ with either probiotics or surface-layer proteins derived from Lactobacillus helveticus R0052 prior to infection with EHEC O157 : H7 strain CL56 (m.o.i. $100: 1,6 \mathrm{~h}, 37{ }^{\circ} \mathrm{C}$ in $5 \% \mathrm{CO}_{2}$ ). Subsequently, cells were washed and stimulated with human recombinant IFN- $\gamma\left(50 \mathrm{ng} \mathrm{ml}{ }^{-1}, 0.5 \mathrm{~h}, 37^{\circ} \mathrm{C}\right)$ followed by whole-cell protein extraction and immunoblotting for tyrosine-phosphorylated STAT-1. Relative to uninfected cells, STAT-1activation was reduced after EHEC O157:H7 infection. Pre-incubation with the probiotic $L$. helveticus R0052 followed by EHEC infection abrogated pathogen-mediated disruption of IFN$\gamma$-STAT-1 signalling. As determined using Transwell inserts, probiotic-mediated protection was independent of epithelial cell contact. In contrast, pre-incubation with boiled L. helveticus R0052, an equal concentration of viable Lactobacillus rhamnosus R0011, or surface-layer proteins $\left(0.14 \mathrm{mg} \mathrm{ml}^{-1}\right)$ did not restore STAT-1 signalling in EHEC-infected cells. The viable probiotic agent L. helveticus R0052 prevented EHEC 0157 : H7-mediated subversion of epithelial cell signal transduction responses.
\end{abstract}

\section{INTRODUCTION}

Outbreaks of enterohaemorrhagic Escherichia coli (EHEC) serotype O157:H7 infection occur frequently across the developed world (Serna \& Boedeker, 2008). This foodborne enteric pathogen is acquired from contaminated foodstuffs and non-chlorinated drinking water (Karch et al., 2005; Maki, 2006; Rangel et al., 2005). In the severest cases of infection ( $10-15 \%$ of cases), the haemolytic uraemic syndrome develops as a systemic complication, leading to patient hospitalization, kidney failure and death (Serna \& Boedeker, 2008; Tarr et al., 2005). Renal disease results from bacterial cytotoxin [Shiga-like toxin (Stx)-1 and -2] production in the gut, release into the systemic circulation and damage to vascular endothelial cells in the renal glomerulus (Blackall \& Marques, 2004). EHEC pathogenesis is also attributed to intimate bacterial adhesion conferred by the locus of enterocyte effacement (LEE) pathogenicity island, the activity of effector proteins

Abbreviations: EHEC, enterohaemorrhagic Escherichia coli; EPEC, enteropathogenic Escherichia coli; IFN, interferon; LEE, locus of enterocyte effacement; STAT-1, signal transducer and activator of transcription-1. secreted through a type three secretion system (T3SS), and pathogen modulation of host cell signal transduction cascades (Bhavsar et al., 2007; Kaper et al., 2004).

EHEC disease pathogenesis includes subversion of epithelial cell signal transduction cascades involved in host innate immune responses to infection (Bhavsar et al., 2007). For instance, EHEC inhibits interferon (IFN)- $\gamma$-stimulated tyrosine phosphorylation of signal transducer and activator of transcription-1 (STAT-1) in multiple cell lines (Ceponis et al., 2003), which is mediated by a bacterially encoded factor (Jandu et al., 2006). EHEC-mediated disruption of STAT-1 activation is independent of EHEC-derived toxins (Stx-1 and Stx-2), the LEE pathogenicity island, the O157: H7 plasmid (pO157), and H7 flagellin (Ceponis et al., 2003). Gene knockout mice provide evidence that the IFN- $\gamma$-Jak1,2-STAT-1 signal transduction cascade is an essential innate immune response required to combat microbial infections (Shtrichman \& Samuel, 2001).

Probiotics are live, non-pathogenic micro-organisms that confer health benefits to the host (Senok et al., 2005). Probotics are increasingly being employed in the management of a variety of human diseases (Servin, 2004). For 
instance, pathogen adhesion and invasion, and changes in epithelial cell permeability induced by enteroinvasive E. coli (Resta-Lenert \& Barrett, 2006), Salmonella typhimurium (Gill et al., 2001; O’Hara et al., 2006; Silva et al., 2004), Shigella flexneri (Tien et al., 2006) and Yersinia enterocolitica (Frick et al., 2007), are prevented using probiotics administered either as a single strain or as combination therapy. Enteric pathogen-induced changes in the activation, expression and secretion of pro-inflammatory cytokines (tumour necrosis factor-alpha; TNF $\alpha$ ) and chemokines (interleukin 8) by epithelial cells are also prevented by probiotics (Frick et al., 2007; O'Hara et al., 2006; Tien et al., 2006).

The aim of the current study was to characterize the effects of the probiotic Lactobacillus helveticus strain R0052 and Lactobacillus rhamnosus R0011 on EHEC O157:H7 inhibition of STAT-1 activation in response to IFN- $\gamma$. Herein, we show that probiotic-mediated protection against EHEC subversion of the innate immune response is species- and strain-specific, involves heat-labile probiotics, and is independent of direct probiotic contact with epithelial cells.

\section{METHODS}

Tissue culture. Intestine (Int) 407, HEp-2 and Caco-2 epithelial cell lines (American Type Culture Collection) were utilized as in vitro models of infected epithelia. Tissue-culture cells were grown as previously described (Ceponis et al., 2003). Briefly, Int 407 cells were grown in tissue-culture medium composed of minimal essential medium containing $10 \%(\mathrm{v} / \mathrm{v})$ fetal bovine serum and $2 \%(\mathrm{v} / \mathrm{v})$ penicillin-streptomycin. HEp-2 cells were grown in minimal essential medium containing $15 \%(\mathrm{v} / \mathrm{v})$ fetal bovine serum, $2 \%(\mathrm{v} / \mathrm{v})$ sodium bicarbonate, $2.5 \%(\mathrm{v} / \mathrm{v})$ penicillin-streptomycin, and $1 \%(\mathrm{v} / \mathrm{v})$ fungizone (all from Invitrogen Canada). Caco-2 cells were grown in Dulbecco's modified Eagle medium (DMEM) containing $10 \%(\mathrm{v} / \mathrm{v})$ fetal bovine serum, $2 \%(\mathrm{v} / \mathrm{v})$ penicillin-streptomycin, $1.1 \%$ sodium pyruvate and $0.3 \%(\mathrm{v} / \mathrm{v})$ human transferrin (all from Invitrogen Canada)

Cells were grown in T25 flasks (Corning) at $37{ }^{\circ} \mathrm{C}$ in $5 \% \mathrm{CO}_{2}$ until confluent $\left(2 \times 10^{6}-3 \times 10^{6}\right.$ cells per flask $)$. Once confluent, cells were trypsinized $\left(0.05 \%\right.$ trypsin) for $20 \mathrm{~min}$ at $37{ }^{\circ} \mathrm{C}$ in $5 \% \mathrm{CO}_{2}$ and centrifuged at 500 r.p.m. for $5 \mathrm{~min}$ in a Beckman Coulter centrifuge. Cell pellets were resuspended in tissue-culture medium, seeded into $6 \mathrm{~cm}$ Petri dishes (Becton Dickinson Labware), and grown at $37^{\circ} \mathrm{C}$ in $5 \% \mathrm{CO}_{2}$ until confluent. Twenty-four hours prior to bacterial infection, cells were incubated in antibiotic-free and serum-free tissue-culture medium (Jandu et al., 2006). To determine whether the benefits of probiotics required epithelial cell contact, cultured epithelia were grown in a 12 -well tissue-culture plate fitted with $0.4 \mu \mathrm{m}$ pore-size Transwell filter membranes (Costar). Bacteria were physically separated from epithelial cells by growing the epithelia in the top chamber of the Transwell, while bacteria were added into the bottom chamber (Ceponis et al., 2003).

Bacterial strains and growth conditions. Bacterial strains used in this study included EHEC strain CL56 (serotype O157:H7), enteropathogenic E. coli (EPEC) strain E2348/69 (serotype O127:H6) and the non-pathogenic laboratory E. coli strain HB101. EHEC O157:H7, strain CL56, which produces both Stx-1 and Stx-2, was originally isolated from a child with haemorrhagic colitis and haemolytic uraemic syndrome at the Hospital for Sick Children (Toronto, ON, Canada) (Karmali et al., 1985). The eae-positive EPEC strain E2348/69 and non-pathogenic E. coli strain HB101 were used for comparative purposes. Bacteria were grown as previously described (Ceponis et al., 2003; Jandu et al., 2006, 2007). Briefly, strains were grown on $5 \%$ sheep blood agar plates (Becton Dickinson) at $37^{\circ} \mathrm{C}$ for $24 \mathrm{~h}$. Prior to infecting epithelial cells, bacteria were inoculated into $10 \mathrm{ml}$ Penassay broth (Becton Dickinson) and grown overnight at $37^{\circ} \mathrm{C}$.

Gram-positive probiotics L. helveticus R0052 (formerly Lactobacillus acidophilus R0052; Naser et al., 2006) and L. rhamnosus R0011 were provided by Institut Rosell-Lallemand. As previously described (Johnson-Henry et al., 2005), probiotics were grown in $10 \mathrm{ml} \mathrm{de}$ Man, Rogosa and Sharpe (MRS) broth (Becton Dickinson) at $37^{\circ} \mathrm{C}$ for $24 \mathrm{~h}$ prior to pre-treatment of epithelial cells. For pre-treatment studies, confluent epithelial cells were pre-treated with an overnight growth of probiotics $\left(5 \times 10^{8}\right.$ c.f.u. $\left.\mathrm{ml}^{-1}\right)$ at $37{ }^{\circ} \mathrm{C}$ in $5 \% \mathrm{CO}_{2}$ for $3 \mathrm{~h}$. The probiotic strain tested was then left on the epithelial cells (i.e. cells were not washed), and EHEC O157:H7 was applied directly onto the cells plus probiotics for a $6 \mathrm{~h}$ infection period. For cotreatment studies, probiotics were added to epithelial cells at the same time as EHEC; both the probiotic and the pathogen were then left with the epithelial cells for the entire $6 \mathrm{~h}$ infection period.

To determine whether viable probiotics were required for protection, the effects of boiled lactobacilli $\left(100{ }^{\circ} \mathrm{C}, 60 \mathrm{~min}\right)$, surface-layer proteins (Johnson-Henry et al., 2007), conditioned medium, and culture supernatants derived from L. helveticus R0052 were examined. Surface-layer proteins $\left(0.14 \mathrm{mg} \mathrm{ml}^{-1}\right)$ were reconstituted in antibiotic-free tissue-culture medium and then incubated with epithelial cells at $37{ }^{\circ} \mathrm{C}$ in $5 \% \mathrm{CO}_{2}$ for $3 \mathrm{~h}$ prior to EHEC infection. For conditioned medium, epithelial cells were incubated with L. helveticus $\mathrm{R} 0052$ at $37{ }^{\circ} \mathrm{C}$ in $5 \% \mathrm{CO}_{2}$ for $9 \mathrm{~h}$. Medium was then collected, centrifuged at 3000 r.p.m. for $10 \mathrm{~min}$, passed through a $0.45 \mu \mathrm{m}$ filter and stored at $-20{ }^{\circ} \mathrm{C}$ until use. Culture supernatants were collected after an overnight growth of L. helveticus R0052 and centrifuged at 3000 r.p.m. for $10 \mathrm{~min}$. Supernatants were then collected and filterconcentrated using an Amicon ultracentrifugal filter column (Millipore). Columns were centrifuged at 3000 r.p.m. for $30 \mathrm{~min}$ and samples were then stored at $-20{ }^{\circ} \mathrm{C}$. Epithelial cells were preincubated for $3 \mathrm{~h}$ at $37{ }^{\circ} \mathrm{C}$ in $5 \% \mathrm{CO}_{2}$ in either conditioned medium or culture supernatant followed by EHEC O157: H7 infection for $6 \mathrm{~h}$.

\section{Epithelial cell infection and whole-cell protein extraction.} Epithelial cells were either pre-treated with probiotics ( $L$. helveticus R0052 or L. rhamnosus R0011) prior to infection, or co-incubated with probiotics and EHEC. EHEC infection was performed at an m.o.i. of 100:1 (Ceponis et al., 2003). Briefly, an overnight bacterial culture was centrifuged at 3000 r.p.m. for $5 \mathrm{~min}$, the supernatant decanted and the bacterial pellet resuspended in $0.1 \mathrm{ml}$ tissue-culture medium without antibiotics or fetal bovine serum. The bacterial suspension was then used to infect $\left(2 \times 10^{8}\right.$ c.f.u. $\left.\mathrm{ml}^{-1}\right)$ confluent epithelial cells grown in $6 \mathrm{~cm}$ Petri dishes for $6 \mathrm{~h}$ at $37{ }^{\circ} \mathrm{C}$ in $5 \%$ $\mathrm{CO}_{2}$. At the end of the infection period, cell viability assays were performed for some experiments, while whole-cell protein extraction was performed in others.

Epithelial cell viability was determined by the exclusion of Trypan blue (Sigma). Briefly, after infection of cultured epithelial cells with EHEC O157:H7 alone, probiotics alone or probiotics and EHEC, cells were trypsinized and centrifuged. Cell pellets were resuspended in $10 \mathrm{ml}$ tissue-culture medium, and an aliquot of the cell suspension was combined with $0.4 \%$ Trypan blue in a $1: 3(\mathrm{v} / \mathrm{v})$ ratio, vortexed well and placed onto a haemocytometer slide. Using bright-field microscopy, viable and non-viable cells were then enumerated, with the number of viable cells calculated as a percentage of the total cell count. 
At the end of the $6 \mathrm{~h}$ infection period, cells were washed once with sterile PBS ( $\mathrm{pH} 7.4$ ) to remove non-adherent bacteria and then stimulated with human recombinant IFN- $\gamma$ (50 ng ml ${ }^{-1}$; R\&D Systems) for $30 \mathrm{~min}$ at $37{ }^{\circ} \mathrm{C}$ in $5 \% \mathrm{CO}_{2}$ (Ceponis et al., 2003; Jandu et al., 2006, 2007). Subsequently, cells were washed three times with ice-cold PBS and collected, using a rubber scraper, into a final $1 \mathrm{ml}$ volume of PBS.

Whole-cell protein extracts were prepared as described previously (Ceponis et al., 2003; Jandu et al., 2006, 2007). Briefly, cell extracts were centrifuged at 13000 r.p.m. for $20 \mathrm{~s}$ at $20{ }^{\circ} \mathrm{C}$, and the supernatants were decanted and pellets resuspended in $0.15 \mathrm{ml}$ RIPA buffer ( $1 \%$ Nonidet P-40, $0.5 \%$ sodium deoxylate, $0.1 \%$ SDS in PBS) supplemented with $150 \mathrm{mM} \mathrm{NaCl}, 50 \mathrm{mM}$ sodium fluoride, $1 \mathrm{mM}$ sodium orthovanadate, $20 \mu \mathrm{g}$ PMSF $\mathrm{ml}^{-1}, 15 \mu \mathrm{g}$ aprotinin $\mathrm{ml}^{-1}, 2 \mu \mathrm{g}$ leupeptin $\mathrm{ml}^{-1}$ and $2 \mu \mathrm{g}$ pepstatin $\mathrm{A} \mathrm{ml}^{-1}$ (all from Sigma Aldrich), vortexed well and left on ice for $20 \mathrm{~min}$. Resuspended pellets were centrifuged again at 12000 r.p.m. for $10 \mathrm{~min}$ at $4{ }^{\circ} \mathrm{C}$, and supernatants were stored at $-80{ }^{\circ} \mathrm{C}$ until further analysis by immunoblotting.

SDS-PAGE and immunoblotting. SDS-PAGE and immunoblotting were conducted as previously described (Ceponis et al., 2003; Jandu et al., 2006, 2007). Briefly, cell extracts were prepared for SDS-PAGE by combining loading buffer with whole protein extracts in a $1: 2(\mathrm{v} / \mathrm{v})$ ratio. Samples were heated at $100{ }^{\circ} \mathrm{C}$ for $3 \mathrm{~min}$, loaded into precast $10 \%$ polyacrylamide gels (Ready Gel; Bio-Rad Laboratories) and electrophoresed at $150 \mathrm{~V}$ for $1 \mathrm{~h}$. Migrated protein was transferred onto nitrocellulose membranes (BioTrace NT; Pall Corporation) at $110 \mathrm{~V}$ for $1.5-2 \mathrm{~h}$ at $4{ }^{\circ} \mathrm{C}$.

Nitrocellulose membranes were initially incubated in Odyssey blocking buffer (LI-COR Biosciences) for $1 \mathrm{~h}$ at $20{ }^{\circ} \mathrm{C}$, followed by incubation with primary and secondary antibodies. Primary antibodies for STAT-1 bind to both the alpha and beta isoforms of this signalling molecule (Baran-Marszak et al., 2004). Antibodies employed included an anti-latent-STAT-1 antibody (Santa Cruz Biotechnologies; 1:5000 dilution in Odyssey buffer) and an antiphospho-STAT-1 antibody (Cell Signalling for HEp-2 cells; Zymed for Int 407 cells; both at $1: 1000$ dilution). An anti- $\beta$-actin primary antibody (1:5000 dilution; Sigma) was employed as a loading control. Membranes were incubated with primary antibodies at $4{ }^{\circ} \mathrm{C}$ overnight on a shaker and then washed four times with PBS $+0.1 \%$ Tween ( 5 min per wash). Secondary antibodies, including IRDye 800 goat anti-rabbit IgG (1:20 000 dilution; Rockland Immunochemicals) and Alexa Fluor 680 goat anti-mouse IgG $(1: 20000$ dilution; Molecular Probes) were incubated for $1 \mathrm{~h}$ at $20{ }^{\circ} \mathrm{C}$ on a shaker. Subsequently, membranes were washed four times with PBS $+0.1 \%$ Tween (5 min per wash); the final wash step included PBS without Tween.

The Odyssey Infrared Imaging System (LI-COR Biosciences) was used to scan nitrocellulose membranes and detect positively stained bands. Scanning was performed with both the 700 and $800 \mathrm{~nm}$ channels on, at a resolution of $169 \mu \mathrm{m}$ (Jandu et al., 2007). The integrated intensity of all bands was calculated using automated software provided by the manufacturer. For immunoblots with dual anti-latent-STAT-1 and anti- $\beta$-actin or dual anti-phospho-STAT- 1 and anti- $\beta$-actin staining, the integrated intensity values for anti-latent-STAT-1 and antiphospho-STAT-1 bands were normalized using intensity values obtained for corresponding anti- $\beta$-actin bands (Jandu et al., 2007). Values obtained from bands of uninfected IFN- $\gamma$-stimulated cells were then set to $100 \%$, with samples derived from microbial treatments calculated as a percentage relative to uninfected cells.

Statistics. Results are presented as means \pm SEM. To determine statistical significances $(P<0.05)$ between multiple groups, ANOVA was performed. Where indicated, a two-tailed, paired Student's $t$ test was performed to determine statistical difference in levels of STAT-1 activation between two groups (Norman \& Streiner, 2003).

\section{RESULTS}

\section{EHEC 0157: H7 inhibits tyrosine phosphorylation of STAT-1 in Int 407 epithelial cells}

Immunoblotting and densitometry were employed to determine the effects of EHEC O157:H7 on STAT-1 signalling in Int 407 cells. As shown by immunoblotting in Fig. 1(a), IFN- $\gamma$-dependent STAT-1 tyrosine phosphoryla-
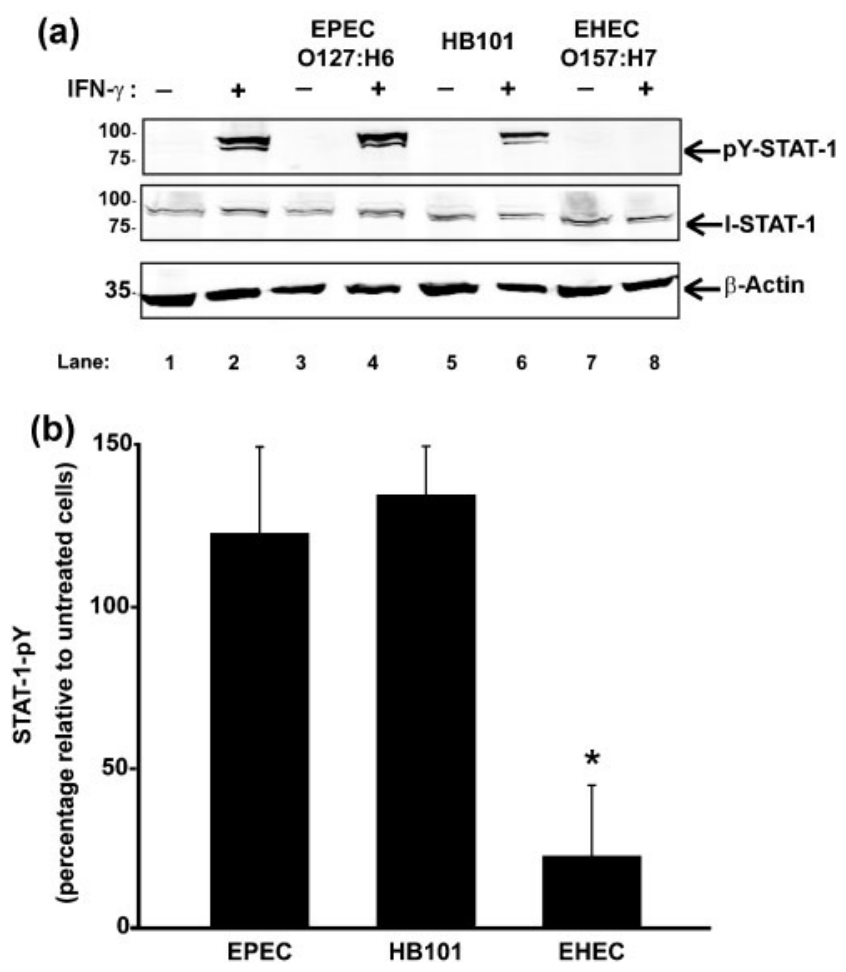

Fig. 1. EHEC O157:H7 disrupts IFN- $\gamma$-induced tyrosine phosphorylation of STAT-1 in Int 407 cells. Int 407 cells were infected with $E$. coli strains (m.o.i. $100: 1$ for $6 \mathrm{~h}$ at $37{ }^{\circ} \mathrm{C}$ in $5 \% \mathrm{CO}_{2}$ ) and then incubated in the absence or presence of IFN- $\gamma\left(50 \mathrm{ng} \mathrm{ml}^{-1}\right)$ for $0.5 \mathrm{~h}$ at $37{ }^{\circ} \mathrm{C}$ in $5 \% \mathrm{CO}_{2}$. Whole-cell protein extracts were collected and immunoblots probed with anti-latent-STAT-1 (ISTAT-1), anti-phospho-STAT-1 (pY-STAT-1) or anti- $\beta$-actin primary antibodies, followed by the respective secondary antibodies. Positively stained bands were detected using an IR imaging system. $\beta$-Actin served as a protein loading control. (a) Lanes: 1 and 2, uninfected epithelial cells in the absence and presence of IFN- $\gamma$, respectively; 3 and 4 , cells infected with EPEC strain E2348/69 (serotype O127: $\mathrm{H} 6$ ); 5 and 6, cells infected with a non-pathogenic laboratory E. coli, strain HB101; 7 and 8, cells infected with EHEC O157:H7 strain CL56. Only the EHEC strain (lane 8) blocked IFN- $\gamma$ activation of STAT-1. (b) Densitometry of positively stained bands was quantified using software embedded in the IR scanner (three separate experiments; ${ }^{\star} P<0.05$, ANOVA). 
tion was reduced in cultured epithelial cells infected with EHEC O157:H7 compared with uninfected cells. In contrast, tyrosine phosphorylation of STAT-1 in Int 407 cells treated with IFN- $\gamma$ remained intact when cells were infected with either EPEC strain E2348/69 (serotype O127: H6), or a non-pathogenic laboratory E. coli strain, HB101 (Fig. 1a). Quantification of immunoblots by densitometry showed that STAT-1 tyrosine phosphorylation was reduced to $20.6 \pm 5.6 \% \quad(n=10 ; \quad P<0.05$, ANOVA) in EHEC-infected epithelial cells, compared with uninfected epithelial cells (Fig. 1b). Levels of STAT-1 phosphorylation in EPEC-infected and HB101-infected epithelial cells were $122.7 \pm 35.0 \%(n=3 ; P>0.05)$ and $135.3 \pm 51 \% \quad(n=3 ; P>0.05)$, respectively, relative to uninfected epithelial cells (Fig. 1b). Collectively, these findings are consistent with previous reports using other epithelial cell lines (Ceponis et al., 2003; Jandu et al., 2006, 2007).

\section{L. helveticus $\mathbf{R 0 0 5 2}$ protects against EHEC 0157 : H7-induced disruption of STAT-1 signalling}

As shown in Fig. 2(a), tyrosine phosphorylation of STAT-1 in response to IFN- $\gamma$ remained intact in Int 407 cells pretreated $(3 \mathrm{~h})$ with $L$. helveticus $\mathrm{R} 0052$ followed by infection with EHEC O157: H7 (6 h). By contrast, co-incubation of Int 407 cells with L. helveticus R0052 and EHEC O157 : H7 $(6 \mathrm{~h})$ did not prevent pathogen-mediated inhibition of STAT-1 activation. As shown by densitometry, preincubation of epithelial cells with the probiotic L. helveticus R0052 maintained STAT-1 activation in EHEC-infected epithelial cells: $100.7 \pm 34.3 \%$, relative to uninfected epithelial cells $(n=6 ; P<0.05$, ANOVA) (Fig. 2b). Coincubation of Int 407 cells with L. helveticus R0052 and EHEC did not prevent microbial inhibition of STAT-1 activation $(24.7 \pm 6.3 \%$, relative to uninfected cells; $n=6$, $P>0.05$ ) (Fig. 2b). Incubation of L. helveticus R0052 alone with Int 407 cells did not alter IFN- $\gamma$-stimulated STAT-1 tyrosine phosphorylation $(82.1 \pm 9.8 \%$ and $92.5 \pm 18.7 \%$, for co-incubation and pre-incubation conditions, respectively; $n=4, P>0.05)$ relative to uninfected cells. Taken together, using a STAT-1 tyrosine phosphorylation assay as the outcome measure, these findings indicate that preincubation, but not co-incubation, with probiotics is required to effectively protect epithelial cells from EHECmediated subversion of innate immunity.

As shown in Fig. 3(a), and as in our previous report (Jandu et al., 2007), IFN- $\gamma$-stimulated tyrosine phosphorylation of STAT-1 was reduced after EHEC O157:H7 infection of HEp-2 cells $(13.6 \pm 5.5 \%$, compared with uninfected epithelial cells; $n=9, P<0.05)$. Pre-incubation $(3 \mathrm{~h})$ of HEp-2 cells with L. helveticus R0052 followed by EHEC $\mathrm{O} 157: \mathrm{H} 7$ infection $(6 \mathrm{~h})$ resulted in protection from pathogen-mediated disruption of IFN- $\gamma$-stimulated STAT1 activation (Fig. 3b, $86.2 \pm 17.2 \%$, relative to uninfected epithelial cells; $n=7, P=0.008$, paired Student's $t$ test). $L$. helveticus R0052 alone did not reduce STAT-1 tyrosine (a)
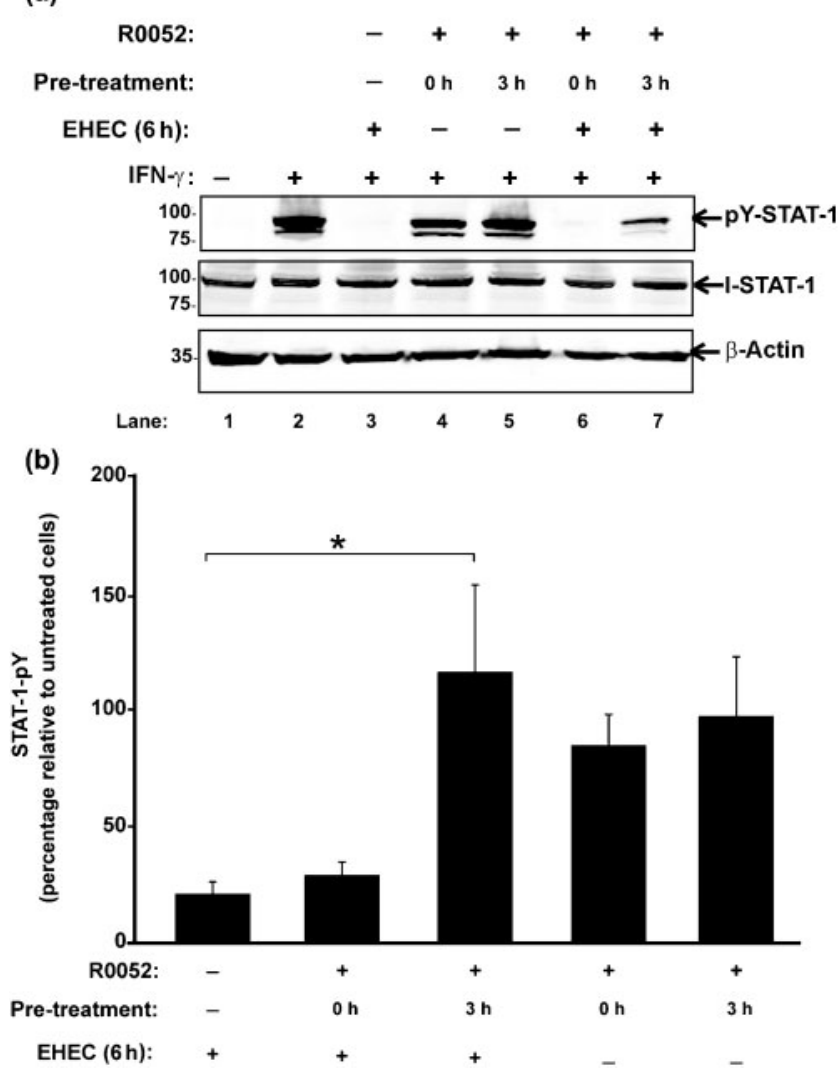

Fig. 2. Pre-incubation with L. helveticus R0052 protects Int 407 cells against EHEC $0157: \mathrm{H} 7$ inhibition of IFN- $\gamma$-induced STAT-1 activation. Int 407 cells were either pre-treated with L. helveticus R0052 (m.o.i. $100: 1$ for $3 \mathrm{~h}$ at $37{ }^{\circ} \mathrm{C}$ in $5 \% \mathrm{CO}_{2}$ ) prior to EHEC O157 : $\mathrm{H} 7$ infection (m.o.i. $100: 1$ for $6 \mathrm{~h}$ at $37{ }^{\circ} \mathrm{C}$ in $5 \% \mathrm{CO}_{2}$ ) or co-treated with L. helveticus R0052 and EHEC O157: H7. Cells were then incubated in the absence or presence of IFN- $\gamma$ ( $50 \mathrm{ng}$ $\mathrm{ml}^{-1}$ ) for $30 \mathrm{~min}$ at $37{ }^{\circ} \mathrm{C}$ in $5 \% \mathrm{CO}_{2}$. Whole-cell protein extracts were collected and immunoblots probed with anti-latent-STAT-1 (I-STAT-1), anti-phospho-STAT-1 (pY-STAT-1) or anti- $\beta$-actin primary antibodies, followed by their respective secondary antibodies. Positively stained bands were detected by using an IR imaging system. (a) Lanes: 1 and 2, uninfected Int 407 epithelial cells in the absence and presence of IFN- $\gamma$, respectively; 3 , EHEC O157: H7 disrupted IFN- $\gamma$-induced STAT-1 phosphorylation; 4 and $5, L$. helveticus R0052 alone did not alter IFN- $\gamma$-stimulated STAT-1 phosphorylation; 6, co-treatment with L. helveticus R0052 did not reverse EHEC 0157 : H7 inhibition of STAT-1 signalling, but pre-incubation of epithelial cells with L. helveticus R0052 prevented EHEC 0157: H7 disruption of STAT-1 activation in Int 407 cells (lane 7). (b) STAT-1 phosphorylation was quantified by image-intensity analysis using software embedded in the IR imaging system (three to five separate experiments; ${ }^{\star} P<0.05$, ANOVA).

phosphorylation in HEp-2 cells $(106.4 \pm 35 \%$ relative to untreated controls; $n=4)$. Pre-incubation $(3 \mathrm{~h})$ of Caco-2 cells with $L$. helveticus R0052 also prevented EHEC O157: H7-mediated inhibition of IFN- $\gamma$-induced tyrosine 

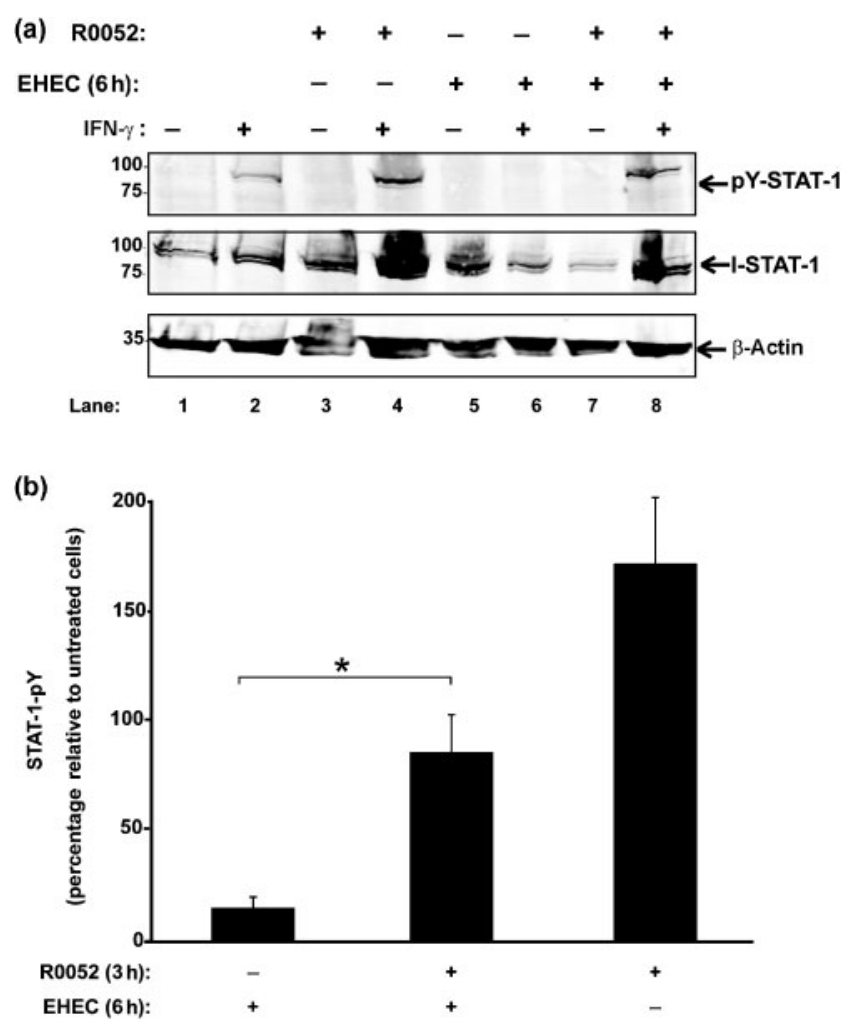

Fig. 3. L. helveticus R0052 prevents EHEC O157:H7-induced inhibition of STAT-1 phosphorylation in HEp-2 cells. HEp-2 cells were pre-treated with L. helveticus R0052 (m.o.i. 100:1 for $3 \mathrm{~h}$ ) and then infected with EHEC $0157: \mathrm{H} 7$ (m.o.i. 100:1 for $6 \mathrm{~h}$ at $37{ }^{\circ} \mathrm{C}$ in $5 \% \mathrm{CO}_{2}$ ). Cells were then incubated in the absence or presence of IFN- $\gamma\left(50 \mathrm{ng} \mathrm{ml}^{-1}\right)$ for $0.5 \mathrm{~h}$ at $37{ }^{\circ} \mathrm{C}$ in $5 \% \mathrm{CO}_{2}$. (a) Lanes: 1 and 2, uninfected HEp-2 epithelial cells in the absence and presence of IFN- $\gamma$, respectively; 3 and 4, L. helveticus R0052 alone did not alter IFN- $\gamma$-stimulated STAT- 1 phosphorylation; 5 and 6, EHEC O157:H7 disrupted IFN- $\gamma$-induced STAT-1 phosphorylation; 7 and 8, pre-treatment of epithelial cells with $L$. helveticus R0052 prevented EHEC 0157: H7 disruption of STAT-1 activation in HEp-2 cells. (b) Densitometry of immunoblots was performed to quantify the integrated intensities of positively staining bands. STAT-1 tyrosine phosphorylation remained intact in epithelial cells pre-incubated with L. helveticus R0052 prior to EHEC 0157: H7 infection (five to seven separate experiments; ${ }^{\star} P<0.05$, ANOVA).

phosphorylation of STAT-1 in polarized Caco-2 intestinal epithelial cells $(87.5 \pm 8.0 \%$ relative to uninfected controls; $n=4)$ (data not shown as a figure).

\section{L. rhamnosus R0011 does not protect epithelial cells against EHEC 0157 : H7-mediated disruption of IFN- $\gamma$-Jak1,2-STAT-1 signalling}

To determine species and strain specificity, L. rhamnosus R0011 (Sherman et al., 2005) was then tested. As shown in Fig. 4(a, b), STAT-1 tyrosine phosphorylation was reduced
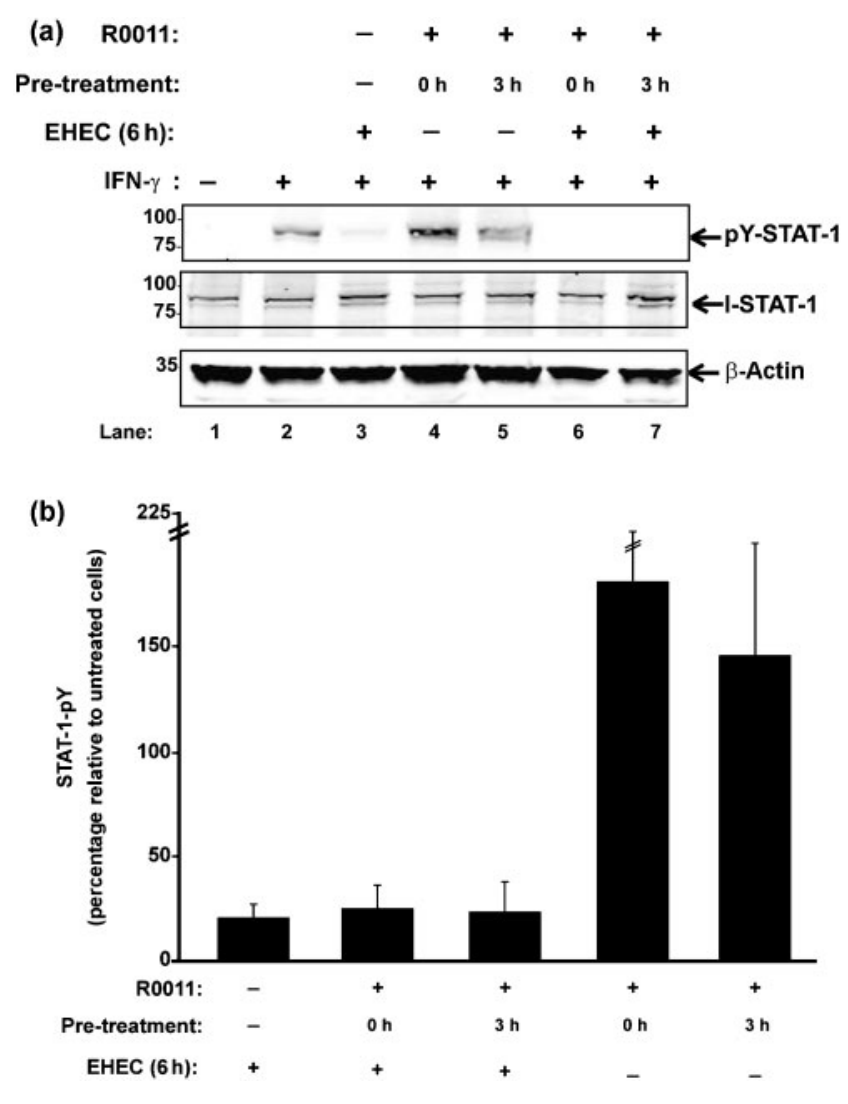

Fig. 4. L. rhamnosus R0011 does not protect Int 407 cells against EHEC 0157:H7 disruption of IFN- $\gamma$-induced STAT-1 activation. Int 407 cells were either pre-treated with $L$. rhamnosus R0011 (m.o.i. $100: 1$ for $3 \mathrm{~h}$ at $37{ }^{\circ} \mathrm{C}$ in $5 \% \mathrm{CO}_{2}$ ) prior to EHEC O157: $\mathrm{H} 7$ infection (m.o.i. $100: 1$ for $6 \mathrm{~h}$ at $37{ }^{\circ} \mathrm{C}$ in $5 \% \mathrm{CO}_{2}$ ) or co-treated with L. rhamnosus R0011 and EHEC O157 : H7. Cells were then stimulated with IFN- $\gamma\left(50 \mathrm{ng} \mathrm{ml}^{-1}\right)$ for $0.5 \mathrm{~h}$ at $37{ }^{\circ} \mathrm{C}$ in $5 \% \quad \mathrm{CO}_{2}$. Whole-cell protein extracts were collected and immunoblots were probed with anti-latent-STAT-1 (I-STAT-1), anti-phospho-STAT-1 (pY-STAT-1) or anti- $\beta$-actin primary antibodies, followed by their respective secondary antibodies. $\beta$-Actin was used as a protein loading control. (a) Positively stained bands were detected using an IR imaging system. Lanes: 1 and 2, uninfected epithelial cells in the absence and presence of IFN- $\gamma$, respectively; 3, EHEC O157:H7 disrupted IFN- $\gamma$-induced STAT1 phosphorylation; 4 and 5, L. rhamnosus R0011 alone did not alter IFN- $\gamma$-stimulated STAT-1 phosphorylation; 6 and $7, L$. rhamnosus R0011 lacked the ability to protect Int 407 cells from EHEC O157:H7-disrupted STAT-1 signalling. (b) STAT-1 phosphorylation was quantified using image-intensity analysis (three separate experiments; $P>0.05$ ).

$(22.7 \pm 14.2 \%$ of the value for untreated controls; $n=3$, $P<0.05)$ in Int 407 cells pre-incubated $(3 \mathrm{~h})$ with $L$. rhamnosus R0011 followed by EHEC O157:H7 infection $(6 \mathrm{~h})$. Phosphorylated STAT-1 levels were also reduced $(24.3 \pm 11.3 \%$ of the value for untreated controls; $n=3$, $P>0.05)$ in Int 407 cells co-incubated with L. rhamnosus R0011 and EHEC. Tyrosine phosphorylation of STAT-1 in 
response to IFN- $\gamma$ was not reduced when Int 407 cells were incubated with $L$. rhamnosus R0011 alone (144.9 $\pm 53.6 \%$ of value for uninfected controls, $n=3, P>0.05)$.

As shown in Fig. 5(a), pre-incubation of HEp-2 cells with L. rhamnosus R0011 (3 h) followed by EHEC infection $(6 \mathrm{~h})$ resulted in STAT-1 tyrosine phosphorylation levels comparable with values observed in HEp-2 cells incubated with EHEC O157: $\mathrm{H} 7$ alone $(7.5 \pm 2.4 \%$ of the value for uninfected epithelial cells; $n=6, P<0.05$ ) (Fig. 5b). As with Int 407 cells, L. rhamnosus R0011 incubated with HEp-2 epithelial cells alone did not alter STAT-1 signalling $(101.7 \pm 1.7 \% ; n=3$ of value for uninfected controls, $P>0.05)$.

\section{Surface-layer proteins derived from $L$. helveticus R0052 do not prevent EHEC 0157 : H7 disruption of IFN- $\gamma$-Jak1,2-STAT-1 signalling}

Differences in the outer cell surface composition of various probiotic strains could explain observed differences between the two probiotics tested (Johnson-Henry et al., 2007). To determine whether surface-layer proteins afford protection against EHEC infection, epithelial cells were pre-incubated $(3 \mathrm{~h})$ with an extract of surface-layer proteins $\left(0.14 \mathrm{mg} \mathrm{ml}^{-1}\right)$ followed by E. coli $\mathrm{O} 157: \mathrm{H} 7$ infection for $6 \mathrm{~h}$. As shown by immunoblotting (Fig. 6a) and by densitometry (Fig. 6b), pre-incubation of epithelial cells with surface-layer protein extracts did not protect epithelial cells against EHEC O157: H7-induced inhibition of STAT-1 tyrosine phosphorylation $(15.0 \pm 8.6 \%$ of value for uninfected controls; $n=3, P<0.05)$. Surface-layer proteins alone did not affect IFN- $\gamma$-stimulated STAT-1 tyrosine phosphorylation $(99.1 \pm 34.5 \%$ relative to uninfected controls; $n=3, P>0.05)$. Higher concentrations of surface-layer protein extracts were not employed due to problems with solubility in the tissue-culture medium (Johnson-Henry et al., 2007).

In addition, live probiotics were required, because boiled $L$. helveticus R0052 did not restore STAT-1 activation in EHEC-infected epithelial cells $(21.8 \pm 9.0 \%$, relative to uninfected cells; $n=3, P>0.05$ ) (data not shown as a figure). Neither conditioned medium nor culture supernatants prepared from L. helveticus R0052 resulted in the recovery of STAT-1 tyrosine phosphorylation in EHECinfected epithelial cells, indicating that viable, intact $L$. helveticus $\mathrm{R} 0052$, rather than secreted products, is required to prevent EHEC subversion of epithelial cell signal transduction responses to infection.

(a)

R0011:

Pre-treatment time:

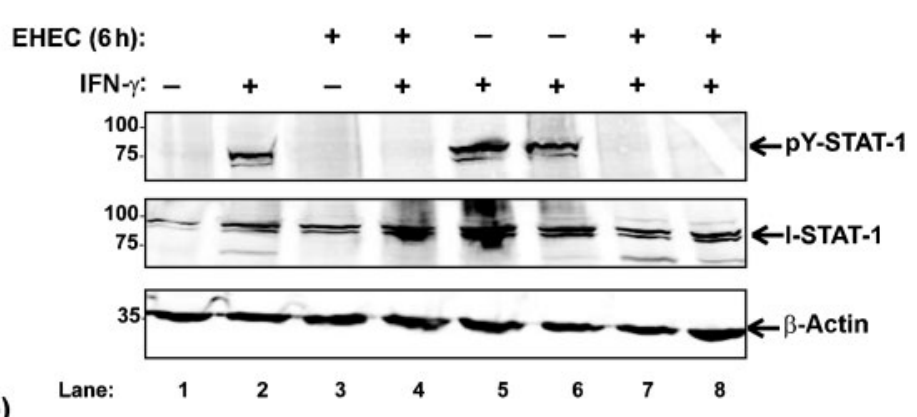

(b)

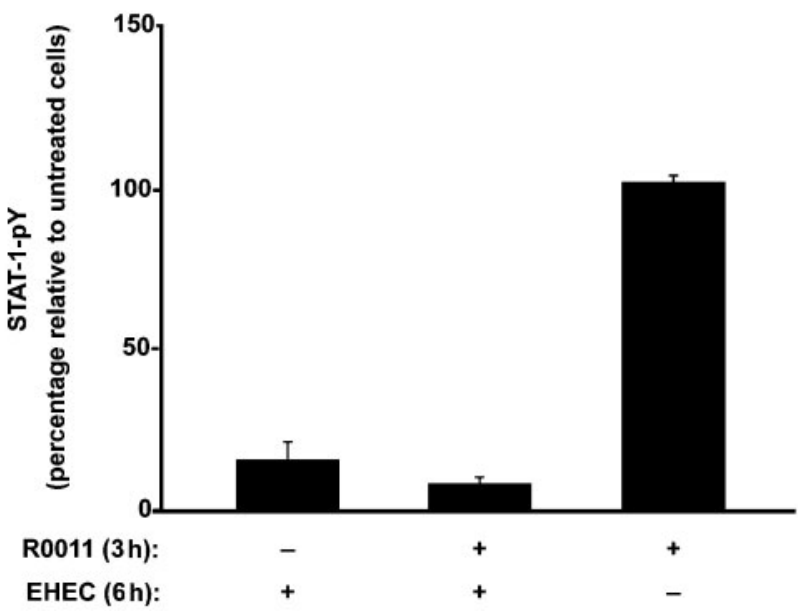

Fig. 5. L. rhamnosus R0011 does not protect HEp-2 epithelial cells from EHEC O157: H7induced inhibition of STAT-1 tyrosine phosphorylation. Cultured epithelial cells were pretreated with L. rhamnosus R0011 (m.o.i. $100: 1$ for $3 \mathrm{~h}$ at $37^{\circ} \mathrm{C}$ in $\left.5 \% \mathrm{CO}_{2}\right)$ and then infected with EHEC O157:H7 (m.o.i. 100:1 for $6 \mathrm{~h}$ at $37{ }^{\circ} \mathrm{C}$ in $5 \% \mathrm{CO}_{2}$ ). Cells were then stimulated with IFN- $\gamma\left(50 \mathrm{ng} \mathrm{ml}^{-1}\right)$ for $0.5 \mathrm{~h}$ at $37{ }^{\circ} \mathrm{C}$ in $5 \% \mathrm{CO}_{2}$. Whole-cell protein extracts were collected for immunoblotting and densitometry of immunoblots was performed to quantify the integrated intensities of positively stained bands. (a) Lanes: 1 and 2, uninfected HEp-2 epithelial cells in the absence and presence of IFN- $\gamma$, respectively; 3 and 4 , EHEC O157:H7 disrupted IFN- $\gamma$-induced STAT-1 phosphorylation; 5 and 6, L. rhamnosus R0011 alone did not alter IFN- $\gamma$-stimulated STAT-1 phosphorylation; 7 and 8 , neither cotreatment $(0 \mathrm{~h})$ nor pre-treatment $(3 \mathrm{~h})$ of epithelial cells with L. rhamnosus R0011 reversed EHEC O157:H7 inhibition of STAT-1 signalling in HEp-2 cells. (b) Densitometry of immunoblots was performed to quantify the integrated intensities of positively stained bands. Controls included uninfected epithelial cells in the absence and presence of IFN- $\gamma$ (six separate experiments; $P>0.05$ ). 


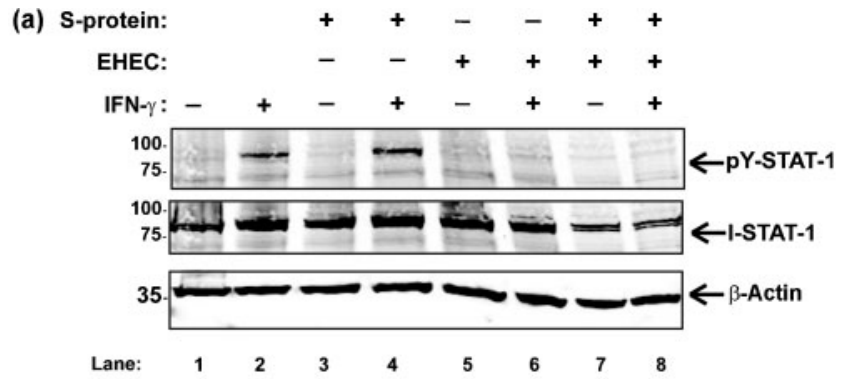

(b)

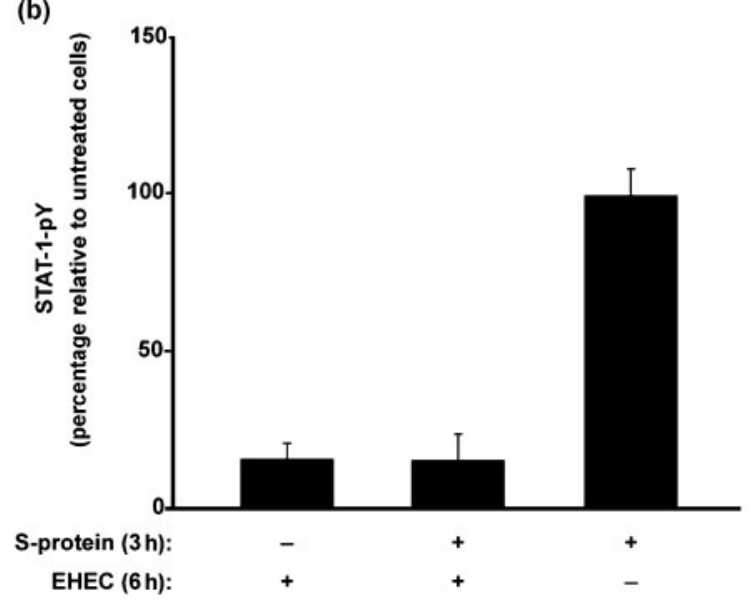

Fig. 6. L. helveticus R0052-derived surface-layer proteins do not protect HEp-2 epithelial cells against EHEC O157: H7-induced inhibition of STAT-1 tyrosine phosphorylation. Cultured epithelial cells were pre-treated with surface-layer proteins (S-protein; $0.14 \mathrm{mg} \mathrm{ml}^{-1}$ for $3 \mathrm{~h}$ at $37{ }^{\circ} \mathrm{C}$ in $5 \% \mathrm{CO}_{2}$ ) and then infected with EHEC O157: $\mathrm{H} 7$ (m.o.i. $100: 1$ for $6 \mathrm{~h}$ at $37{ }^{\circ} \mathrm{C}$ in $5 \% \mathrm{CO}_{2}$ ). Cells were stimulated with IFN- $\gamma\left(50 \mathrm{ng} \mathrm{ml}^{-1}\right)$ for $0.5 \mathrm{~h}$ at $37^{\circ} \mathrm{C}$ in $5 \% \mathrm{CO}_{2}$. Whole-cell protein extracts were collected and immunoblots probed with anti-latent-STAT-1 (I-STAT-1), antiphospho-STAT-1 (pY-STAT-1) or anti- $\beta$-actin primary antibodies, followed by their respective secondary antibodies. (a) Positively staining bands were detected using a commercial IR scanner. Lanes: 1 and 2, uninfected epithelial cells in the absence and presence of IFN- $\gamma$, respectively; 3 and 4 , surface-layer proteins alone did not alter IFN- $\gamma$-stimulated STAT- 1 phosphorylation; 5 and 6, EHEC O157:H7 disrupted IFN- $\gamma$-induced STAT-1 phosphorylation; 7 and 8, pre-treatment with surface-layer proteins did not prevent EHEC 0157:H7-mediated disruption of STAT-1 activation in HEp-2 cells. (b) Positively stained bands on immunoblots were quantified using image-intensity analysis software (three separate experiments; $P>0.05$ ).

\section{L. he/veticus $\mathbf{R 0 0 5 2}$ protection against EHEC 0157 : H7-induced disruption of STAT-1 tyrosine phosphorylation is independent of probiotic contact with epithelial cells}

To determine whether L. helveticus $\mathrm{R} 0052$ requires direct contact with epithelial cells, Transwell studies were conducted. As shown in Fig. 7(a), IFN- $\gamma$-stimulated STAT-1 tyrosine phosphorylation was inhibited only when

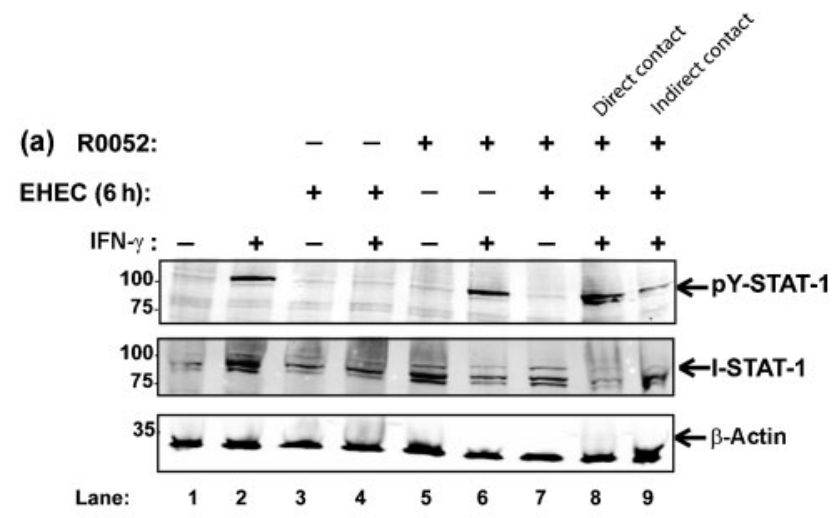

(b)

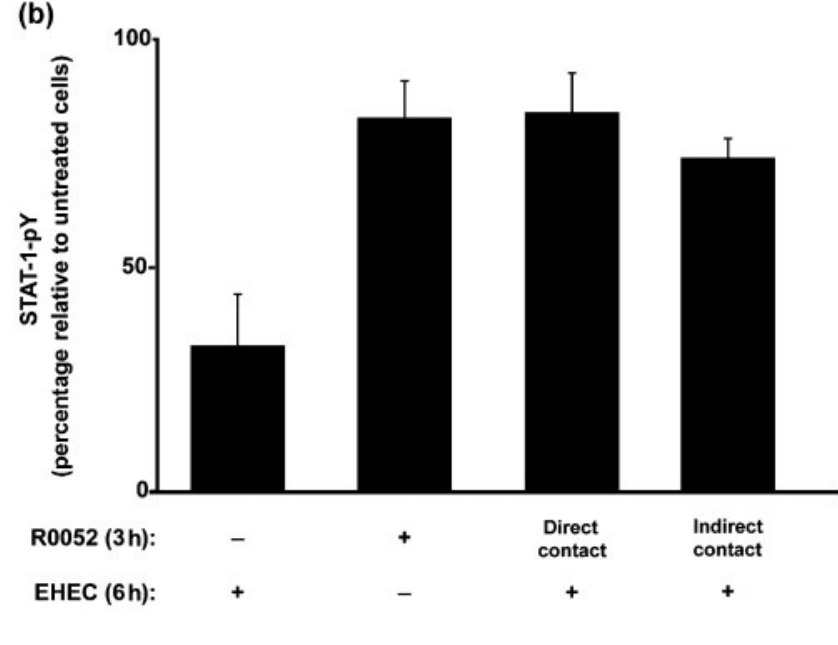

Fig. 7. Contact-independent protection of L. helveticus R0052 against EHEC 0157:H7-mediated inhibition of STAT-1 activation. HEp-2 epithelial cells were grown in the upper chamber of a 12-well Transwell fitted with a $0.4 \mu \mathrm{m}$ pore-size filter membrane. Probiotics were added either to the upper chamber in direct contact with epithelial cells or to the lower chamber separated from cells by a filter membrane (3 h; m.o.i. $100: 1$ at $37{ }^{\circ} \mathrm{C}$ in $5 \%$ $\mathrm{CO}_{2}$ ). EHEC strain CL56 serotype $0157: \mathrm{H} 7$ was then added to the upper chamber (m.o.i. 100:1 for $6 \mathrm{~h}$ at $37{ }^{\circ} \mathrm{C}$ in $5 \% \mathrm{CO}_{2}$ ). After washings, epithelial cells were stimulated with IFN- $\gamma$ (50 $\mathrm{ng}$ $\mathrm{ml}^{-1}$ ) for $0.5 \mathrm{~h}$ at $37{ }^{\circ} \mathrm{C}$ in $5 \% \mathrm{CO}_{2}$. Whole-cell protein extracts were then collected for immunoblotting, and blots were scanned using an IR scanner. (a) Positively staining bands were detected using a commercial IR scanner. Lanes: 1 and 2, uninfected epithelial cells in the absence and presence of IFN- $\gamma$, respectively; 3 and 4, EHEC O157:H7 disrupted IFN- $\gamma$-induced STAT-1 phosphorylation; 5 and 6, L. rhamnosus R0052 alone did not alter IFN- $\gamma$-stimulated STAT-1 phosphorylation; 7, pre-treatment of epithelial cells with $L$. rhamnosus R0052 followed by EHEC infection in the absence of IFN- $\gamma$. After IFN- $\gamma$ stimulation, $L$. rhamnosus R0052 in either direct contact (lane 8) or indirect contact (lane 9) with epithelial cells prevented EHEC inhibition of STAT-1 activation. (b) Densitometry was performed to quantify the integrated intensities of positively staining bands (four separate experiments; $P>0.05$ ). 
EHEC was in direct contact with epithelial cells $(32.0 \pm 11.7 \%$ of value for uninfected controls; $n=4)$. Probiotic amelioration of EHEC-induced inhibition of STAT-1 tyrosine phosphorylation occurred either when $L$. helveticus R0052 was in direct contact with epithelia $(83.9 \pm 8.7 \%$ of value for untreated cells; $n=4)$ or when it was separated from epithelial cells by a filter membrane $(73.6 \pm 4.4 \%$ of value for untreated cells; $n=4)$. $L$. helveticus R0052 alone did not alter STAT-1 tyrosine phosphorylation $(82.2 \pm 8.6 \%$ of value for uninfected controls; $n=4$ ) (Fig. 7b).

\section{DISCUSSION}

Herein we show, for the first time to our knowledge, that the probiotic strain L. helveticus $\mathrm{R} 0052$ protects cultured epithelial cells against EHEC O157:H7 subversion of the IFN- $\gamma$-Jak1,2-STAT-1 signal transduction cascade. In contrast, another probiotic, strain L. rhamnosus R0011, did not protect host epithelial cells against EHEC-mediated inhibition of STAT-1 signalling. Probiotic protection of STAT-1 signal transduction required both pre-treatment time and viable probiotics, as neither co-treatment with $L$. helveticus nor boiled R0052 prevented EHEC inhibition of tyrosine phosphorylation of STAT-1. In addition, $L$. helveticus R0052 prevents EHEC pathogenesis irrespective of probiotic contact with epithelial cells.

Previous studies have shown probiotic-mediated protection of cultured epithelial cells in response to EHEC O157:H7 infection. In a previous study, pre-treatment $(3 \mathrm{~h})$ of epithelial cell(s) with probiotics was required to preserve epithelial cell integrity during EHEC infection, whereas co-incubation of probiotics and the EHEC pathogen did not maintain epithelial cell integrity (Sherman et al., 2005). In a subsequent study, L. helveticus R0052-derived surface-layer proteins were shown to preserve epithelial cell integrity during EHEC infection (Johnson-Henry et al., 2007). However, in the present study, L. helveticus R0052-derived surface-layer proteins did not prevent EHEC O157:H7-induced subversion of STAT- 1 activation by IFN- $\gamma$. Collectively, these results indicate that mechanism(s) by which L. helveticus preserves STAT-1 tyrosine phosphorylation in cultured epithelial cells during EHEC infection occur independently of surface-layer proteins.

Other probiotics can also preserve epithelial cell integrity and maintain intracellular signal transduction cascades in response to pathogens. For instance, Resta-Lenert \& Barrett (2003) have shown that the probiotics Streptococcus thermophilus and Lactobacillus acidophilus protect epithelial cells (HT-29 and Caco-2) against enteroinvasive E. colimediated disruption of epidermal growth factor signalling. Consistent with our results, pre-treatment of epithelial cells with probiotics was required to provide protection against the effects of EHEC on host cell signal transduction. In addition, live probiotics are required to ameliorate the adverse effects of pathogens, since neither antibiotic-killed (Resta-Lenert \& Barrett, 2003) nor heat-killed (Sherman et al., 2005; this study) probiotics prevent the pathogenic effects of E. coli enteropathogens on cultured epithelial cells.

Potential mechanisms of probiotic-mediated protection against pathogens include their ability to maintain intestinal epithelial integrity (Madsen et al., 2001), production of bacteriocins (Corr et al., 2007), increased mucin production and secretion from goblet cells (Mack et al., 2003), and immunomodulatory effects (Boirivant \& Strober, 2007). Colonization resistance refers to the ability of some probiotics to guard against pathogen binding via the formation of a protective barrier between epithelial cells and the infecting organism (Eutamene \& Bueno, 2007; Fedorak \& Madsen, 2004). To test this hypothesis, we employed a Transwell model of infection to evaluate the effects of direct and indirect contact of L. helveticus R0052 with cultured epithelial cells as a mechanism maintaining STAT-1 signalling in EHEC-infected cells. The results demonstrate that $L$. helveticus $\mathrm{R} 0052$ protects epithelial cells against EHEC subversion of STAT-1 tyrosine phosphorylation independent of probiotic contact with host cells.

Our study focuses on the ability of L. helveticus R0052 to retain the innate immune signalling cascade: inhibition of IFN- $\gamma$-stimulated STAT-1 tyrosine phosphorylation by EHEC O157:H7 infection. There are several implications arising from the results of this study. As a pro-inflammatory cytokine, IFN- $\gamma$ is generated in response to infection by enteric pathogens. In vivo studies using Citrobacter rodentium infection in mice, as a model of EHEC infection (Mundy et al., 2006), have shown that this results in IFN- $\gamma$ recruitment into the lamina propria and increased transcript expression of this cytokine in infected mouse colonic mucosa (Higgins et al., 1999). In addition, C. rodentium infection of IFN- $\gamma$ gene knockout mice results in increased pathogen burden, enhanced gut injury and greater mortality (Bry \& Brenner, 2004; Simmons et al., 2002, 2003). Taken together, these in vivo studies and our in vitro results indicate that microbial evasion of the IFN- $\gamma$-Jak1,2-STAT-1 signalling cascade represents an immune evasion strategy employed by these non-invasive enteric pathogens.

In summary, we have shown that $L$. helveticus R0052 maintains IFN- $\gamma$-Jak1,2-STAT-1 activation following EHEC O157:H7 infection of multiple epithelial cell lines. Viable L. helveticus R0052 is required for protection, while contact with epithelial cells is not necessary. Future research efforts should focus on characterizing the molecular interactions between this probiotic and host epithelial cells. Also, studies should describe the influence of this probiotic on the expression of EHEC O157:H7 virulence factors.

\section{ACKNOWLEDGEMENTS}

This research was supported by operating grants from the Crohn's and Colitis Foundation of Canada (Fay Shapiro Cutler Research 
Award) and the Canadian Institutes of Health Research (CIHR). N. J. is the recipient of a CIHR/Canadian Digestive Health Foundation Doctoral Research Award, a CIHR Cell Signals Strategic Training Program STP-53877 Trainee Award and an Open Fellowship Award from the University of Toronto. P. M. S. is the recipient of a Canada Research Chair (tier 1) in gastrointestinal disease.

\section{REFERENCES}

Baran-Marszak, F., Feuillard, J., Najjar, I., Le Clorennec, C., Bechet, J. M., Dusanter-Fourt, I., Bornkamm, G. W., Raphael, M. \& Fagard, R. (2004). Differential roles of STAT $1 \alpha$ and STAT1 $\beta$ in fludarabineinduced cell cycle arrest and apoptosis in human B cells. Blood 104 2475-2483.

Bhavsar, A. P., Guttman, J. A. \& Finlay, B. B. (2007). Manipulation of host-cell pathways by bacterial pathogens. Nature 449, 827-834.

Blackall, D. P. \& Marques, M. B. (2004). Hemolytic uremic syndrome revisited: Shiga toxin, factor $\mathrm{H}$, and fibrin generation. Am J Clin Pathol 121 (Suppl.), S81-S88.

Boirivant, M. \& Strober, W. (2007). The mechanism of action of probiotics. Curr Opin Gastroenterol 23, 679-692.

Bry, L. \& Brenner, M. B. (2004). Critical role of T cell-dependent serum antibody, but not the gut-associated lymphoid tissue, for surviving acute mucosal infection with Citrobacter rodentium, an attaching and effacing pathogen. J Immunol 172, 433-441.

Ceponis, P. J., McKay, D. M., Ching, J. C., Pereira, P. \& Sherman, P. M. (2003). Enterohemorrhagic Escherichia coli O157:H7 disrupts Stat1-mediated gamma interferon signal transduction in epithelial cells. Infect Immun 71, 1396-1404.

Corr, S. C., Li, Y., Riedel, C. U., O'Toole, P. W., Hill, C. \& Gahan, C. G. (2007). Bacteriocin production as a mechanism for the antiinfective activity of Lactobacillus salivarius UCC118. Proc Natl Acad Sci U S A 104, 7617-7621.

Eutamene, H. \& Bueno, L. (2007). Role of probiotics in correcting abnormalities of colonic flora induced by stress. Gut 56, 1495-1497.

Fedorak, R. N. \& Madsen, K. L. (2004). Probiotics and prebiotics in gastrointestinal disorders. Curr Opin Gastroenterol 20, 146-155.

Frick, J. S., Fink, K., Kahl, F., Niemiec, M. J., Quitadamo, M., Schenk, K. \& Autenrieth, I. B. (2007). Identification of commensal bacterial strains that modulate Yersinia enterocolitica and dextran sodium sulfateinduced inflammatory responses: implications for the development of probiotics. Infect Immun 75, 3490-3497.

Gill, H. S., Shu, Q., Lin, H., Rutherfurd, K. J. \& Cross, M. L. (2001). Protection against translocating Salmonella typhimurium infection in mice by feeding the immuno-enhancing probiotic Lactobacillus rhamnosus strain HN001. Med Microbiol Immunol 190, 97-104.

Higgins, L. M., Frankel, G., Douce, G., Dougan, G. \& MacDonald, T. T. (1999). Citrobacter rodentium infection in mice elicits a mucosal Th1 cytokine response and lesions similar to those in murine inflammatory bowel disease. Infect Immun 67, 3031-3039.

Jandu, N., Ceponis, P. J., Kato, S., Riff, J. D., McKay, D. M. \& Sherman, P. M. (2006). Conditioned medium from enterohemorrhagic Escherichia coli-infected T84 cells inhibits signal transducer and activator of transcription 1 activation by gamma interferon. Infect Immun 74, 1809-1818.

Jandu, N., Shen, S., Wickham, M. E., Prajapati, R., Finlay, B. B., Karmali, M. A. \& Sherman, P. M. (2007). Multiple seropathotypes of verotoxin-producing Escherichia coli (VTEC) disrupt interferon- $\gamma$ induced tyrosine phosphorylation of signal transducer and activator of transcription (Stat)-1. Microb Pathog 42, 62-71.
Johnson-Henry, K. C., Nadjafi, M., Avitzur, Y., Mitchell, D. J., Ngan, B. Y., Galindo-Mata, E., Jones, N. L. \& Sherman, P. M. (2005). Amelioration of the effects of Citrobacter rodentium infection in mice by pretreatment with probiotics. J Infect Dis 191, 2106-2117.

Johnson-Henry, K. C., Hagen, K. E., Gordonpour, M., Tompkins, T. A. \& Sherman, P. M. (2007). Surface-layer protein extracts from Lactobacillus helveticus inhibit enterohaemorrhagic Escherichia coli O157:H7 adhesion to epithelial cells. Cell Microbiol 9, 356-367.

Kaper, J. B., Nataro, J. P. \& Mobley, H. L. (2004). Pathogenic Escherichia coli. Nat Rev Microbiol 2, 123-140.

Karch, H., Tarr, P. I. \& Bielaszewska, M. (2005). Enterohaemorrhagic Escherichia coli in human medicine. Int J Med Microbiol 295, 405-418.

Karmali, M. A., Petric, M., Lim, C., Fleming, P. C., Arbus, G. S. \& Lior, H. (1985). The association between idiopathic hemolytic uremic syndrome and infection by verotoxin-producing Escherichia coli. J Infect Dis 151, 775-782.

Mack, D. R., Ahrne, S., Hyde, L., Wei, S. \& Hollingsworth, M. A. (2003). Extracellular MUC3 mucin secretion follows adherence of Lactobacillus strains to intestinal epithelial cells in vitro. Gut 52, 827833.

Madsen, K., Cornish, A., Soper, P., McKaigney, C., Jijon, H., Yachimec, C., Doyle, J., Jewell, L. \& De Simone, C. (2001). Probiotic bacteria enhance murine and human intestinal epithelial barrier function. Gastroenterology 121, 580-591.

Maki, D. G. (2006). Don't eat the spinach - controlling foodborne infectious disease. N Engl J Med 355, 1952-1955.

Mundy, R., Girard, F., FitzGerald, A. J. \& Frankel, G. (2006). Comparison of colonization dynamics and pathology of mice infected with enteropathogenic Escherichia coli, enterohaemorrhagic E. coli and Citrobacter rodentium. FEMS Microbiol Lett 265, 126-132.

Naser, S. M., Hagen, K. E., Vancanneyt, M., Cleenwerck, I., Swings, J. \& Tompkins, T. A. (2006). Lactobacillus suntoryeus Cachat and Priest 2005 is a later synonym of Lactobacillus helveticus (Orla-Jensen 1919) Bergey et al. 1925 (Approved Lists 1980). Int J Syst Evol Microbiol 56, 355-360.

Norman, G. R. \& Streiner, D. L. (2003). PDQ Statistics, 3rd edn. Hamilton, ON: B. C. Decker.

O'Hara, A. M., O'Regan, P., Fanning, A., O'Mahony, C., Macsharry, J., Lyons, A., Bienenstock, J., O'Mahony, L. \& Shanahan, F. (2006). Functional modulation of human intestinal epithelial cell responses by Bifidobacterium infantis and Lactobacillus salivarius. Immunology 118, 202-215.

Rangel, J. M., Sparling, P. H., Crowe, C., Griffin, P. M. \& Swerdlow, D. L. (2005). Epidemiology of Escherichia coli O157: H7 outbreaks, United States, 1982-2002. Emerg Infect Dis 11, 603-609.

Resta-Lenert, S. \& Barrett, K. E. (2003). Live probiotics protect intestinal epithelial cells from the effects of infection with enteroinvasive Escherichia coli (EIEC). Gut 52, 988-997.

Resta-Lenert, S. \& Barrett, K. E. (2006). Probiotics and commensals reverse TNF- $\alpha$ - and IFN- $\gamma$-induced dysfunction in human intestinal epithelial cells. Gastroenterology 130, 731-746.

Senok, A. C., Ismaeel, A. Y. \& Botta, G. A. (2005). Probiotics: facts and myths. Clin Microbiol Infect 11, 958-966.

Serna, A., 4th \& Boedeker, E. C. (2008). Pathogenesis and treatment of Shiga toxin-producing Escherichia coli infections. Curr Opin Gastroenterol 24, 38-47.

Servin, A. L. (2004). Antagonistic activities of lactobacilli and bifidobacteria against microbial pathogens. FEMS Microbiol Rev 28, 405-440.

Sherman, P. M., Johnson-Henry, K. C., Yeung, H. P., Ngo, P. S., Goulet, J. \& Tompkins, T. A. (2005). Probiotics reduce enterohemor- 
rhagic Escherichia coli O157:H7- and enteropathogenic E. coli O127:H6-induced changes in polarized T84 epithelial cell monolayers by reducing bacterial adhesion and cytoskeletal rearrangements. Infect Immun 73, 5183-5188.

Shtrichman, R. \& Samuel, C. E. (2001). The role of gamma interferon in antimicrobial immunity. Curr Opin Microbiol 4, 251-259.

Silva, A. M., Barbosa, F. H., Duarte, R., Vieira, L. Q., Arantes, R. M. \& Nicoli, J. R. (2004). Effect of Bifidobacterium longum ingestion on experimental salmonellosis in mice. J Appl Microbiol 97, 29-37.

Simmons, C. P., Goncalves, N. S., Ghaem-Maghami, M., BajajElliott, M., Clare, S., Neves, B., Frankel, G., Dougan, G. \& MacDonald, T. T. (2002). Impaired resistance and enhanced pathology during infection with a noninvasive, attaching-effacing enteric bacterial pathogen, Citrobacter rodentium, in mice lacking IL-12 or IFN- $\gamma$. J Immunol 168, 1804-1812.
Simmons, C. P., Clare, S., Ghaem-Maghami, M., Uren, T. K., Rankin, J., Huett, A., Goldin, R., Lewis, D. J., MacDonald, T. T. \& other authors (2003). Central role for B lymphocytes and $\mathrm{CD} 4{ }^{+} \mathrm{T}$ cells in immunity to infection by the attaching and effacing pathogen Citrobacter rodentium. Infect Immun 71, 5077-5086.

Tarr, P. I., Gordon, C. A. \& Chandler, W. L. (2005). Shiga-toxinproducing Escherichia coli and haemolytic uraemic syndrome. Lancet 365, 1073-1086.

Tien, M. T., Girardin, S. E., Regnault, B., Le Bourhis, L., Dillies, M. A., Coppee, J. Y., Bourdet-Sicard, R., Sansonetti, P. J. \& Pedron, T. (2006). Anti-inflammatory effect of Lactobacillus casei on Shigellainfected human intestinal epithelial cells. J Immunol 176, 12281237.

Edited by: B. Kenny 